\title{
Genetic Parameters for Milk Somatic Cell Score and Relationships with Production Traits in Primiparous Dairy Sheep
}

\author{
V. Riggio, ${ }^{\star 1}$ R. Finocchiaro, ${ }^{*}$ J. B. C. H. M. van Kaam,† B. Portolano, ${ }^{*}$ and H. Bovenhuis \\ ${ }^{*}$ Dipartimento S.En.Fi.Mi.Zo.-Sezione Produzioni Animali, Università degli Studi di Palermo, Viale delle Scienze-Parco d'Orleans, \\ 90128 Palermo, Italy \\ †Istituto Zooprofilattico Sperimentale della Sicilia A. Mirri, Via G. Marinuzzi 3, 90129 Palermo, Italy \\ $\ddagger$ Animal Breeding and Genetics Group, Wageningen Institute of Animal Sciences, Wageningen University, PO Box 338, \\ $6700 \mathrm{AH}$ Wageningen, the Netherlands
}

\begin{abstract}
A total of 13,066 first-lactation test-day records of 2,277 Valle del Belice ewes from 17 flocks were used to estimate genetic parameters for somatic cell scores (SCS) and milk production traits, using a repeatability test-day animal model. Heritability estimates were low and ranged from 0.09 to 0.14 for milk, fat, and protein yields, and contents. For SCS, the heritability of 0.14 was relatively high. The repeatabilities were moderate and ranged from 0.29 to 0.47 for milk production traits. The repeatability for SCS was 0.36 . Flock-test-day explained a large proportion of the variation for milk production traits, but it did not have a big effect on SCS. The genetic correlations of fat and protein yields with fat and protein percentages were positive and high, indicating a strong association between these traits. The genetic correlations of milk production traits with SCS were positive and ranged from 0.16 to 0.31 . The results showed that SCS is a heritable trait in Valle del Belice sheep and that single-trait selection for increased milk production will also increase SCS.
\end{abstract}

Key words: somatic cell count, milk production, genetic parameter, dairy sheep

\section{INTRODUCTION}

Mastitis is one of the major diseases in dairy cows and ewes and has motivated extensive research toward improved udder sanitation and mastitis control (ElSaied et al., 1998). Selection for improved resistance to mastitis can be done directly by selecting against mastitis itself or indirectly by selecting for a trait correlated with mastitis (e.g., De Haas, 2003). In particular, SCC has been promoted as an accurate indirect method to predict subclinical or clinical mammary infections in

Received May 22, 2006.

Accepted December 5, 2006.

${ }^{1}$ Corresponding author: vriggio@unipa.it dairy cattle and in dairy sheep. As such SCC has also been suggested as a selection criterion for mastitis resistance (Colleau and Le Bihan-Duval, 1995). It has been demonstrated that the occurrence of mastitis causes an increase in somatic cells (e.g., Sordillo et al., 1996). Hence, milk with an elevated SCC is an indication of the occurrence of infection in the udder; and selection for decreased SCC could lead to a reduction in susceptibility to mastitis (e.g., Mrode and Swanson, 1996).

Genetic parameters for SCC are required to study possibilities of changing SCC by means of selection. Commonly, SCC is log-transformed to SCS. Genetic studies of SCS in dairy sheep are more recent and less frequent than in dairy cattle. The few available genetic studies are on a limited number of breeds; for example, on the Churra (Baro et al., 1994; El-Saied et al., 1998) and Lacaune (Barillet et al., 2001; Rupp et al., 2001, 2003) breeds and the estimates are usually based on average SCS during the lactation. Furthermore, information on the genetic relationship between SCS and milk yield and composition is lacking, and no references are reported in literature on dairy sheep reared in the south of Mediterranean area, where the husbandry system and the management are very different from those adopted for the breeds reared (i.e., Lacaune and Churra) in the north of the Mediterranean area.

The aim of this study was to evaluate genetic aspects of SCS and the relationships between SCS and milk yield, and fat and protein contents and yields in primiparous Valle del Belice ewes using a repeatability testday animal model (Ptak and Schaeffer, 1993).

\section{MATERIALS AND METHODS}

The original data set used for this study included 16,883 records of 3,004 primiparous ewes. Data were collected by the University of Palermo between 1998 and 2003 in 17 Valle del Belice flocks. Test-day records of milk yield, fat percentage, fat yield, protein percentage, protein yield, and SCC were collected at approxi- 
mately monthly intervals, following an A4 recording scheme (ICAR, 1992). All ewes were milked twice daily, and the milk of both daily milkings was analyzed. Fat and protein percentages and SCC were calculated as the weighted average of the morning and evening milking, where weighting is according to the corresponding milk yield.

Records were removed when ewes had an abortion and when both of the ewe's parents were unknown. After editing, the data set consisted of 13,066 observations on 2,277 ewes. The pedigree file consisted of 4,369 animals; in addition to the 2,277 animals with records, 246 sires and 1,846 dams were included. On average, the sires served at least 2 of the 17 flocks under study, and they had 11.34 daughters.

The average number of milk production records per ewe was 5.74, and the average number of SCC testdays per ewe was 5.24. Test-day SCC were converted to SCS using a base 2 logarithmic function: $\mathrm{SCS}=\log _{2}$ $(\mathrm{SCC} / 100)+3$ (Ali and Shook, 1980).

The test-day traits analyzed as response variables were milk yield, fat and protein percentages and yields, and SCS. Variance components and genetic parameters for each trait were estimated using ASREML (Gilmour et al., 2002). Several models were tested to explore the fitted factors and to optimize the analysis; the repeatability test-day animal model reported below was the model with the highest coefficient of determination:

$$
\begin{aligned}
& y_{i j k l m}=\mu+F T D_{i}+Y P S_{j}+L S_{k}+\beta_{1} D I M_{i j k l m} \\
& +\beta_{2} \exp \left(-0.05 \times D I M_{i j k l m}\right)+A_{l}+P E_{l}+e_{i j k l m},
\end{aligned}
$$

where $y_{i j k l m}$ is the test-day trait's measurement; $\mu$ is the population mean; $F T D_{i}$ is the random effect of flock by test-day interaction $i$ (626 levels); YPS $S_{j}$ is the fixed effect of year $\times$ season of lambing interaction $j$, where the season of lambing was equal to 1 if a ewe gave birth in the period January through June, otherwise it was equal to 2 (11 levels); $L S_{k}$ is the fixed effect of litter size class $k$ (2 levels, single or multiple born lambs); $D I M_{i j k l m}$ and $\exp \left(-0.05 \times D I M_{i j k l m}\right)$ are 2 covariates used to model the shape of lactation curves (Wilmink, 1987); $A_{l}$ is the random additive genetic effect of the individual $l\left(4,369\right.$ levels); $P E_{l}$ is the random permanent environmental effect on the individual $l$ (2,277 levels); $e_{i j k l m}$ is the random residual effect.

All known relationships among individuals were considered in the animal model. Heritabilities $\left(\mathrm{h}^{2}\right)$ and repeatabilities $(r)$ were calculated as

$$
\mathrm{h}^{2}=\frac{\sigma_{\mathrm{A}}^{2}}{\sigma_{\mathrm{A}}^{2}+\sigma_{\mathrm{E}_{\mathrm{p}}}^{2}+\sigma_{\mathrm{E}_{\mathrm{t}}}^{2}}, \mathrm{r}=\frac{\sigma_{\mathrm{A}}^{2}+\sigma_{\mathrm{E}_{\mathrm{p}}}^{2}}{\sigma_{\mathrm{A}}^{2}+\sigma_{\mathrm{E}_{\mathrm{p}}}^{2}+\sigma_{\mathrm{E}}^{2}},
$$

Table 1. Descriptive statistics ${ }^{1}$ of test-day traits

\begin{tabular}{lccc}
\hline Daily measurement & Mean & SD & CV (\%) \\
\hline Milk yield (g) & 1,167 & 592 & 51 \\
Fat $(\%)$ & 6.80 & 1.47 & 22 \\
Fat yield (g) & 76.1 & 38.1 & 50 \\
Protein $(\%)$ & 5.48 & 0.75 & 14 \\
Protein yield $(\mathrm{g})$ & 62.6 & 30.8 & 49 \\
SCC $\left(\times 10^{3}\right.$ cells $\left./ \mathrm{mL}\right)$ & 1,484 & 3,648 & 246 \\
SCS & 6.89 & 2.17 & $31^{2}$ \\
\hline
\end{tabular}

${ }^{1}$ Based on 13,066 records for milk production traits and on 11,938 records for SCC and SCS.

${ }^{2}$ The constant is not subtracted from Ali and Shook's (1980) formula to calculate the CV for SCS.

where $\sigma_{A}^{2}$ is the additive genetic variance, $\sigma_{E_{p}}^{2}$ is the permanent environmental variance, and $\sigma_{E_{t}}^{2}$ is the temporary environmental variance.

Bivariate analyses were used to estimate phenotypic and genetic correlations. The model was the same as for the univariate analyses. Estimated variance components from the univariate analyses were used as starting values for the bivariate analyses.

\section{RESULTS}

Means, standard deviations, and coefficients of variation of the test-day traits are given in Table 1. The daily average milk yield was $1,167 \mathrm{~g}$, fat yield was $76.1 \mathrm{~g}$, and protein yield was $62.6 \mathrm{~g}$. The mean SCC was 1,484 $\left(\times 10^{3}\right.$ cells $\left./ \mathrm{mL}\right)$, and the mean SCS was 6.89.

The coefficients of variation for milk, fat, and protein yields were around $50 \%$. The coefficients of variation for fat and protein percentages were considerably lower.

The coefficient of variation for SCC was $246 \%$, whereas the coefficient of variation for SCS was $31 \%$.

Phenotypic variances after adjustment for fixed effects and flock $\times$ test-day interaction (FTD), the heritabilities, the repeatabilities, and the proportions of variance due to FTD are in Table 2. Heritability estimates for milk yield and milk composition traits were low and varied between 0.09 and 0.14 . Standard errors of the heritability estimates were between 0.02 and 0.03 . The heritability estimate for SCS was 0.14 with a standard error of 0.03 .

The proportion of variation explained by FTD is large for all milk production traits; in particular, this proportion is larger than 0.50 for yield traits. Unlike the milk production traits, FTD does not have a big effect on SCS (0.08).

Repeatability estimates for all milk production traits and SCS ranged between 0.29 and 0.47 and the standard errors were always around 0.01 . The lowest estimate was found for fat percentage. 
Table 2. Phenotypic variance $\left(\sigma_{\mathrm{p}}^{2}\right)$, heritability $\left(\mathrm{h}^{2}\right)$, repeatability $(\mathrm{r})$, and flock-test-day $(\mathrm{FTD})$ fraction $( \pm \mathrm{SE})$ for test-day variables

\begin{tabular}{lcccc}
\hline Trait & $\sigma_{\mathrm{p}}^{21}$ & $\mathrm{~h}^{2} \pm \mathrm{SE}$ & $\mathrm{r} \pm \mathrm{SE}$ & $\mathrm{FTD}^{2} \pm \mathrm{SE}$ \\
\hline Milk yield (g) & 130,617 & $0.12 \pm 0.03$ & $0.47 \pm 0.01$ & $0.52 \pm 0.02$ \\
Fat (\%) & 0.95 & $0.09 \pm 0.02$ & $0.29 \pm 0.01$ & $0.46 \pm 0.02$ \\
Fat yield (g) & 594 & $0.14 \pm 0.03$ & $0.44 \pm 0.01$ & $0.51 \pm 0.02$ \\
Protein (\%) & 0.29 & $0.14 \pm 0.03$ & $0.41 \pm 0.01$ & $0.36 \pm 0.02$ \\
Protein yield (g) & 345 & $0.12 \pm 0.03$ & $0.47 \pm 0.01$ & $0.56 \pm 0.02$ \\
SCS & 3.95 & $0.14 \pm 0.03$ & $0.36 \pm 0.01$ & $0.08 \pm 0.01$ \\
\hline
\end{tabular}

\footnotetext{
${ }^{1}$ Sum of the additive genetic, permanent, and temporary environmental variances.

${ }^{2}$ Ratio of the flock-test-day variance and the sum of the additive genetic, permanent environment, temporary environment, and flock-test-day variances.
}

Estimates of genetic and phenotypic correlations are in Table 3. The standard errors of the estimated genetic correlations ranged from 0.02 to 0.18 , and for the phenotypic correlations, the standard errors were around 0.01 . No estimates of correlations are reported between milk production and fat and protein yields. In these cases, the analysis did not converge, probably because the estimates were very close to unity. The genetic correlation between fat and protein yields was strong and positive (0.95). The genetic and phenotypic correlations between milk yield and fat content were equal to 0.19 and to -0.13 , whereas the genetic and phenotypic correlations between milk yield and protein content were -0.04 and -0.23 , respectively. The genetic and phenotypic correlations between fat and protein content were 0.74 and 0.53 , respectively.

Estimated genetic correlations between SCS and milk production traits were all positive. The estimates ranged from 0.16 to 0.31 . The standard errors for the genetic correlations were high and ranged from 0.14 to 0.16 . Phenotypic correlations of SCS with milk, fat, and protein yields were negative $(-0.12,-0.05$, and -0.05$)$, but positive with fat and protein contents $(0.14$ and $0.25)$.

\section{DISCUSSION}

The means for fat and protein percentages were 6.80 and $5.48 \%$, respectively. Cappio-Borlino et al. (1997) reported values of 6.84 for fat and 5.07 for protein in the same breed. The mean SCC was $1,484\left(\times 10^{3}\right.$ cells/ $\mathrm{mL}$ ) and similar to the value of 1,501 reported by Gonzalo et al. (1994). The mean SCS was higher than the value of 3.34 obtained by Barillet et al. (2001) in the Lacaune breed and the 3.80 found by Serrano et al. (2003) in the Manchega breed, using a lactation mean. However, this value is in the range reported in literature (from 5.26 to 12.1) for test-day models (i.e., ElSaied et al., 1998; Othmane et al., 2002).

The coefficients of variation calculated for milk production traits were in agreement with the coefficients of variation found in other studies (Baro et al., 1994; El-Saied et al., 1998; Hamann et al., 2004). Coefficients of variation of $50 \%$ for fat yield, $47 \%$ for protein yield, $25 \%$ for fat percentage and $19 \%$ for protein percentage have been calculated, based on the results reported by Hamann et al. (2004).

The coefficient of variation for SCC obtained in this study was consistent with the value of $238.27 \%$ reported by Baro et al. (1994). Such a high value for the coefficient of variation is due to the skewed distribution of SCC. The coefficient of variation for SCS was $31 \%$ and similar to the one reported by Baro et al. (1994) in Churra sheep (28\%) but lower than the value of 53\% calculated based on the results reported by Hamann et al. (2004) in East Friesian sheep. Instead of calculating the coefficient of variation for SCS, it is more appropriate to calculate the coefficient of variation for the

Table 3. Genetic (above the diagonal) and phenotypic (below the diagonal) correlations $\left( \pm \mathrm{SE}^{1}\right)$ among testday variables

\begin{tabular}{|c|c|c|c|c|c|c|}
\hline & $\begin{array}{c}\text { Milk yield } \\
(\mathrm{g})\end{array}$ & $\begin{array}{l}\text { Fat } \\
(\%)\end{array}$ & $\begin{array}{l}\text { Fat yield } \\
(\mathrm{g})\end{array}$ & $\begin{array}{l}\text { Protein } \\
(\%)\end{array}$ & $\begin{array}{l}\text { Protein yield } \\
\text { (g) }\end{array}$ & SCS \\
\hline Milk & & $0.19 \pm 0.18$ & - & $-0.04 \pm 0.18$ & - & $0.23 \pm 0.16$ \\
\hline Fat $(c$ & -0.13 & & $0.45 \pm 0.15^{2}$ & $0.74 \pm 0.09^{2}$ & $0.33 \pm 0.17$ & $0.16 \pm 0.16$ \\
\hline Fat yield (g) & - & 0.27 & & $0.14 \pm 0.16$ & $0.95 \pm 0.02^{2}$ & $0.31 \pm 0.15^{2}$ \\
\hline Proteir & -0.23 & 0.53 & -0.04 & & $0.19 \pm 0.17$ & $0.24 \pm 0.14$ \\
\hline Protein yield (g) & - & -0.01 & 0.88 & 0.02 & & $0.31 \pm 0.16$ \\
\hline SCS & -0.12 & 0.14 & -0.05 & 0.25 & -0.05 & \\
\hline
\end{tabular}

${ }^{1}$ For phenotypic correlations, the SE are $\leq 0.01$.

${ }^{2}$ These correlation estimates are significantly different from $0(P<0.05)$. 
log-transformed SCC; that is, without adding the constant of 3 (Ali and Shook, 1980). The coefficient of variation for the log-transformed SCC is $56 \%$, which is in the same order as the coefficients of variation for milk, fat, and protein yields.

The heritability estimate for test-day milk yield was lower than those reported for other sheep breeds, which are between 0.15 and 0.24 (El-Saied et al., 1998; Barillet et al., 2001; Othmane et al., 2002). In the literature, heritabilities for fat and protein percentage estimated with test-day models range from 0.06 to 0.39 (i.e., ElSaied et al., 1998; Barillet et al., 2001; Othmane et al., 2002). Hamann et al. (2004) reported heritability estimates of 0.15 for fat and protein yield, which are similar to the estimates found in the present study.

The heritability estimate for SCS falls within the range reported in the literature. Results based on repeatability test-day models for SCS, indicated heritability estimates ranging from 0.04 for the Churra breed (Baro et al., 1994) to 0.16 for the East Friesian breed (Hamann et al., 2004). Other studies reported higher heritability estimates for the average SCS during lactation, from 0.11 to 0.18 (Mavrogenis et al., 1999; Barillet et al., 2001; Rupp et al., 2001). Based on our estimated heritability and repeatability, we expect to find a heritability for the average SCS of 5 observations equal to 0.29 (Falconer and Mackay, 1996).

The low heritability estimates for milk production traits in the present study could be due to parentage errors (Van Vleck, 1970). In the typical Sicilian semiextensive system, it is common practice to have a number of active rams in a flock for unrecorded natural mating from March until December. Therefore, it is often not known with certainty which ram is the sire of an animal. It was hypothesized that the pedigree is more accurate on the female side than on the male side. To test if there were any differences, 2 analyses were performed, one in which all the sires were assumed to be unknown and one in which all the dams were assumed to be unknown. However, we did not find any evidence for the fact that heritability estimates were affected by pedigree errors because the 2 analyses gave very similar heritability estimates that did not differ from the results reported in Table 2. In addition, pedigree errors would also have affected the heritability estimate for SCS. However, our heritability estimate for SCS is relatively high, which conflicts with the hypothesis that estimates were lower due to pedigree errors.

Parameter estimates could also have been influenced by genetic differences between flocks, due to the lack of genetic connections between Valle del Belice flocks. The genetic exchange between flocks is indeed limited; if farmers sell ewes to other producers, this usually occurs after the first lactation (Finocchiaro et al., 2005). Limited genetic links between flocks might hinder the separation of the genetic effects from flock effects. These possible genetic differences can be accounted for by using genetic groups in the model. Therefore, an analysis was carried out in which the base animals within each flock were assigned to different genetic groups. However, this model did not have a big effect on the estimated genetic parameters.

Table 2 shows that FTD effects explain a large proportion of the variation for milk production traits. Management of the Valle del Belice breed is indeed characterized by the enormous variability. Part of this variability is due to the fact that most of the farmers milk ewes by hand, but some of the farms use a milking machine. Furthermore, the lambing system is different from the one adopted in other Mediterranean regions (e.g., Carta et al., 1995; Ligda et al., 2000). The lambing season of the Valle del Belice breed is all year long, starting in July and finishing in the following June, with few lambings in May and June (Finocchiaro et al., 2005). The primiparous ewes usually give birth between December and March. Moreover, sheep are fed natural pastures and fodder crops; supplementation, consisting of hay and sometimes concentrates, is occasionally supplied, for example at the end of gestation (Cappio-Borlino et al., 1997). The grazing possibilities and the chemical and nutritional composition of the feed change annually and also differ among areas. It is interesting to highlight that, unlike the milk yield traits, FTD does not have a big effect on SCS (0.08). This result might be due to the fact that with production traits, FTD affects all ewes. Hence the effects of the flock means on that test-day are large. But with SCS, we are probably looking at just a few high SCC ewes each time, and consequently the FTD effects will remain small.

Repeatability estimates for milk composition traits were moderate and comparable with those reported for dairy ewes (i.e., El-Saied et al., 1998; Othmane et al., 2002; Serrano et al., 2003). The repeatability for SCS (0.36) was consistent with those reported by El-Saied et al. (1998) and Othmane et al. (2002) for the Churra breed ( 0.38 and 0.34 , respectively) but higher than the ones reported by Serrano et al. (2003) for the Manchega breed (0.22) and by Hamann et al. (2004) for the East Friesian breed (0.23).

At present, no genetic and phenotypic correlations between milk and fat yield and between milk and protein yield could be estimated. Correlations estimated using unadjusted data were 0.90 between milk and fat yield and 0.96 between milk and protein yield. Sanna et al. (1997) reported genetic and phenotypic correlations equal to 0.89 and 0.93 between milk and fat yields and 0.94 and 0.97 between milk and protein yields. The 
genetic correlation between fat and protein yields was high and positive, indicating a strong association between these traits. This estimate was higher than the value of 0.68 reported by Hamann et al. (2004) and similar to the 0.93 reported by Sanna et al. (1997). Different genetic correlations from those obtained in this study were reported by Sanna et al. (1997) and by Othmane et al. (2002) between milk yield and fat content and between milk yield and protein content, whereas the phenotypic correlations between these traits obtained in the current study $(-0.13$ and -0.23$)$ are similar to those reported by Sanna et al. (1997). The genetic and phenotypic correlations between fat and protein content were consistent with those reported by Sanna et al. (1997) and by Othmane et al. (2002). Hamann et al. (2004) reported higher genetic correlations between fat yield and fat content $(0.53)$ and between protein yield and protein content $(0.33)$ than those obtained in this study.

Estimated genetic correlations between SCS and milk production traits were all positive, indicating that selection for increased milk yield or fat and protein content will lead to higher SCS. The genetic correlations between production traits and SCS in cattle (for a review see Mrode and Swanson, 1996) resulted mostly in unfavorable genetic correlations (i.e., high milk associated with high level of SCC). In dairy sheep, estimated genetic correlations between milk yield and SCS are very different, ranging from antagonistic, i.e., from 0.04 to 0.18 (Barillet et al., 2001; Rupp et al., 2003), to favorable, i.e., from -0.15 to -0.37 (Baro et al., 1994; ElSaied et al., 1998, 1999). The phenotypic correlation between milk yield and SCS obtained in this study falls in the range (between -0.15 and -0.05 ) reported in the literature (i.e., Baro et al., 1994; El-Saied et al., 1998; Othmane et al., 2002). A genetic correlation equal to 0.31 has been estimated between SCS and fat and protein yields. These estimates are very different from those reported by Hamann et al. (2004) in East Friesian sheep ( -0.04 and 0.06 , respectively). Positive and low to moderate genetic correlations were estimated between SCS and fat content (0.16) and between SCS and protein content $(0.24)$. These results were usually higher than those obtained in other studies (i.e., El-Saied et al., 1998; Othmane et al., 2002; Hamann et al., 2004), although Baro et al. (1994) reported a higher genetic correlation between SCS and protein content (0.37). Therefore, these results suggest that an increase in somatic cells occurs with an increase of fat and protein contents.

\section{CONCLUSIONS}

Heritability estimates for milk production traits in Sicilian Valle del Belice sheep are from 0.09 to 0.14.
These values are lower than those reported for other sheep breeds. The heritability for SCS is 0.14 and falls within the range reported in other studies. There is a substantial effect of flock-test-day on milk production traits. However, the effect of FTD on SCS is limited. The analyses have also shown that SCS is genetically positively correlated to milk, fat and protein yields and contents. Therefore, selection for increased milk production will also increase SCS. However, correlations are not extreme, so simultaneous improvement for milk yield and SCS seems possible.

\section{ACKNOWLEDGMENTS}

The authors would like to acknowledge the Ministero delle Politiche Agricole e Forestali (MiPAF) for financial support for this research (D.M. 302/7303/05). The third author of this manuscript had a Marie Curie European Reintegration Grant of the European Community programme Quality of Life under contract number MERGCT-2004-516458 during this research.

\section{REFERENCES}

Ali, A. K. A., and G. E. Shook. 1980. An optimum transformation for somatic cell concentration in milk. J. Dairy Sci. 63:487-490.

Barillet, F., R. Rupp, S. Mignon-Grasteau, J. M. Astruc, and M. Jacquin. 2001. Genetic analysis of mastitis resistance and somatic cell score in French Lacaune dairy sheep. Genet. Sel. Evol. 33:397-415.

Baro, J. A., J. A. Carriedo, and F. San Primitivo. 1994. Genetic parameters of test day measures for somatic cell count, milk yield and protein percentage of milking ewes. J. Dairy Sci. 77:2658-2662.

Cappio-Borlino, A., B. Portolano, M. Todaro, N. P. P. Macciotta, P. Giaccone, and G. Pulina. 1997. Lactation curves of Valle del Belice dairy ewes for yields of milk, fat and protein estimated with test day models. J. Dairy Sci. 80:3023-3029.

Carta, A., S. R. Sanna, and S. Casu. 1995. Estimating lactation curves and seasonal effects for milk, fat and protein in Sarda dairy sheep with a test day model. Livest. Prod. Sci. 44:37-44.

Colleau, J. J., and E. Le Bihan-Duval. 1995. A simulation study of selection methods to improve mastitis resistance of dairy cows. J. Dairy Sci. 78:659-671.

De Haas, Y. 2003. Somatic cell count patterns. Improvement of udder health by genetics and management. PhD Thesis. Wageningen Univ., Wageningen, the Netherlands.

El-Saied, U. M., J. A. Carriedo, L. F. De la Fuente, and F. San Primitivo. 1999. Genetic parameters of lactation cell counts and milk and protein yields in dairy ewes. J. Dairy Sci. 82:639-644.

El-Saied, U. M., J. A. Carriedo, and F. San Primitivo. 1998. Heritability of test day somatic cell counts and its relationship with milk yield and protein percentage in dairy ewes. J. Dairy Sci. 81:2956-2961.

Falconer, D. S., and T. F. C. Mackay. 1996. Introduction to Quantitative Genetics. 4th ed. Longman Group Ltd., Harlow, UK.

Finocchiaro, R., J. B. C. H. M. van Kaam, B. Portolano, and I. Misztal. 2005. Effect of heat stress on production of Mediterranean dairy sheep. J. Dairy Sci. 88:1855-1864.

Gilmour, A. R., B. J. Gogel, B. R. Cullis, S. J. Welham, and R. Thompson. 2002. ASReml Guide Release 1.0, VSN International Ltd., Hemel Hempstead, UK.

Gonzalo, C., J. A. Carriedo, J. A. Baro, and F. San Primitivo. 1994. Factors influencing variation of test day milk yield, somatic cell count, fat, and protein in dairy sheep. J. Dairy Sci. 77:1537-1542. 
Hamann, H., A. Horstick, A. Wessels, and O. Distl. 2004. Estimation of genetic parameters for test day milk production, somatic cell score and litter size at birth in East Friesian ewes. Livest. Prod. Sci. 87:153-160.

ICAR. 1992. International Committee for Animal Recording. International Regulations for milk recording in sheep. Institut de l'élevage, Department Génétique ei Contrôle des Performances, Paris, France.

Ligda, C., G. Gabriilidis, T. Papadopulos, and A. Georgoudis. 2000. Estimation of genetic parameters for production traits of Chios sheep using a multitrait animal model. Livest. Prod. Sci. 66:217-222.

Mavrogenis, A. P., A. Koumas, and G. Gavrielidis. 1999. The inheritance of somatic cell counts (index of mastitis) in Chios sheep. Pages 389-392 in Proc. 6th Int. Symp. Milking of Small Rumin., Athens, Greece. Wageningen Pers, Wageningen, the Netherlands.

Mrode, R. A., and G. J. T. Swanson. 1996. Genetic and statistical properties of somatic cell count and its suitability as an indirect means of reducing the incidence of mastitis in dairy cattle. Anim. Breed. Abstr. 64:847-857.

Othmane, M. H., L. F. De La Fuente, J. A. Carriedo, and F. San Primitivo. 2002. Heritability and genetic correlations of test day milk yield and composition, individual laboratory cheese yield, and somatic cell count for dairy ewes. J. Dairy Sci. 85:2692-2698.
Ptak, E., and L. R. Schaeffer. 1993. Use of test-day yields for genetic evaluation of dairy sires and cows. Livest. Prod. Sci. 34:23-24.

Rupp, R., G. Lagriffoul, J. M. Astruc, and F. Barillet. 2001. Genetic parameters for milk somatic cell count across first three parities and relationships with production traits in French Lacaune dairy sheep. Page 280 in Proc. 52nd Annu. Meet. Eur. Assoc. Anim. Prod., Budapest, Hungary. Wageningen Pers, Wageningen, the Netherlands.

Rupp, R., G. Lagriffoul, J. M. Astruc, and F. Barillet. 2003. Genetic parameters for milk somatic cell scores and relationships with production traits in French Lacaune dairy sheep. J. Dairy Sci. 86:1476-1481.

Sanna, S. R., A. Carta, and S. Casu. 1997. (Co)variance component estimates for milk composition traits in Sarda dairy sheep using bivariate animal model. Small Rumin. Res. 25:77-82.

Serrano, M., M. D. Pérez-Guzmán, V. Montoro, and J. J. Jurado. 2003. Genetic analysis of somatic cell count and milk traits in Manchega ewes. Mean lactation and test-day approaches. Livest. Prod. Sci. 84:1-10.

Sordillo, L. M., K. Shafer-Weaver, and D. De Rosa. 1996. Immunobiology of the mammary gland. J. Dairy Sci. 80:1851-1865.

Van Vleck, L. D. 1970. Misidentification in estimating the paternal sib correlation. J. Dairy Sci. 53:1469-1474.

Wilmink, J. B. M. 1987. Efficiency of selection for different cumulative milk, fat and protein yields in first lactation. Livest. Prod. Sci. $17: 211-224$. 